\title{
Nutrients Content and Antioxidant Potential of Selected Traditional Vegetables Grown in Malawi
}

\author{
Joseph Yohane Issa (Corresponding Author) \\ Department of Human Nutrition Sciences, School of Food and Nutrition Sciences, Jomo \\ Kenyatta University of Agriculture and Technology, P.O. Box 620000020 Nairobi, Kenya; \\ MUST Institute of Industrial Research and Innovation, Malawi University of Science and \\ Technology, P.O.Box 5196, Limbe, Malawi. E-mail: jissa@must.ac.mw
}

Arnold Onyango, Anselimo Makokha, Judith Okoth

Department of Human Nutrition Sciences, School of Food and Nutrition Sciences, Jomo Kenyatta University of Agriculture and Technology, P.O. Box 620000020 Nairobi, Kenya

Received: March 17, 2021 Accepted: May 11, $2021 \quad$ Published: May 14, 2021

doi:10.5296/jas.v9i2.18424

URL: https://doi.org/10.5296/jas.v9i2.18424

\begin{abstract}
Vegetables provide nutrients, especially minerals and vitamins, and non-nutrient phytochemicals with health benefits. Iron, zinc and vitamin A deficiencies are common in most developing countries yet traditional vegetables that can provide these nutrients grow wildly in most areas. This study evaluated the nutrient contents, phytochemicals and the 2,2-diphenyl-1-picryl hydrazyl (DPPH) radical scavenging activities of five traditional leafy vegetables grown in Malawi, namely Amaranth hybridus (Amaranth ssp.), Moringa oleifera ( Drum stick), Bidens pilosa (Black jack), Corchorus olitorius (Jute mallow) and Ipomea batatas (Sweet potato) leaves. Results from the present study show that beta-carotene ranged from $829.68 \mu \mathrm{g} / 100 \mathrm{~g}$ to $5,791.64$ $\mu \mathrm{g} / 100 \mathrm{~g}$ and Moringa oleifera had the highest concentration. Vitamin C content ranged from 7.93 $\mathrm{mg} / 100 \mathrm{~g}$ to $35.81 \mathrm{mg} / 100 \mathrm{~g}$ and Ipomea batatas leaves had the highest concentration. Zinc concentrations ranged from $4.42 \mathrm{mg} / 100 \mathrm{~g}$ to $10.59 \mathrm{mg} / 100 \mathrm{~g}$. Iron content ranged from 37.22 $\mathrm{mg} / 100 \mathrm{~g}$ to $48.21 \mathrm{mg} / 100 \mathrm{~g}$. Total phenolics content (TPC) ranged from $0.98 \mathrm{~g} / 100 \mathrm{~g}$ to 3.89 $\mathrm{g} / 100 \mathrm{~g}$ with Bidens pilosa leaves having the highest TPC $(3.89 \pm 0.23 \mathrm{~g} / 100 \mathrm{~g})$. Moringa oleifera and Bidens pilosa leaves had significantly higher $(\mathrm{P}<0.05)$ total flavonoids content $(\mathrm{TFC})$ compared to the other vegetables. Total carotenoids content (TCC) ranged from 1,708.68 $\mu \mathrm{g} / 100 \mathrm{~g}$ to $15,041.59 \mu \mathrm{g} / 100 \mathrm{~g}$. Tannins content ranged from $42.94 \mathrm{mg} / 100 \mathrm{~g}$ to $77.16 \mathrm{mg} / 100 \mathrm{~g}$. DPPH radical scavenging activities of the vegetable leaves were in the order of Bidens pilosa > Corchorus olitorius > Moringa oleifera > Ipomea batatas > Amaranth hybridus. The 50\% inhibitory concentration ( $\mathrm{IC}_{50}$ ) values of these vegetables ranged from $12.5 \mu \mathrm{g} / \mathrm{mL}$ to $125 \mu \mathrm{g} / \mathrm{mL}$.
\end{abstract}


Lower $\mathrm{IC}_{50}$ values indicate higher radical scavenging activity. The results suggested that the traditional vegetables under the study can significantly contribute to improved human nutrition and have potential to reduce diseases related to oxidative stress.

Keywords: DPPH radical scavenging activity, nutritional profiles, phytochemicals, vegetables

\section{Introduction}

Vegetables contribute towards more balanced diets worldwide by providing the needed micronutrients and vitamins. Vegetables also provide non-nutritive compounds with health benefits known as phytochemicals that have antioxidant properties. Some vitamins and minerals also play significant roles as antioxidants (Yang \& Keding, 2009). Indigenous or traditional vegetables are underutilized in some regions of the world although they can play significant roles in addressing malnutrition and improving human health. Deficiencies in vitamins and minerals such as iron and zinc are the major nutritional challenges in Sub-Saharan Africa (Etcheverry et al., 2012). Non-communicable diseases, which were formerly thought to be diseases of affluence are also rapidly increasing in these countries and are placing heavy heath and financial burdens especially on the poor (Ayasan, 2015). Traditional leafy vegetables such as amaranth and solanum species are excellent sources of iron. The concentrations of iron and other micronutrients in the vegetables might be influenced by growing conditions such as soil $\mathrm{pH}$, soil nutrients, water and climate (Uusiku et al., 2010). These vegetables have non-nutrient phytochemicals such as polyphenols with potential to reduce the risks of diseases related to oxidative stress (Gunathilake \& Ranaweera, 2018). The phytochemicals shield cells from free radical damage by acting as antioxidants (Maria et al., 2019). Previous research has linked vegetables consumption with reduced risks of degenerative diseases such as cancer (Mathew et al., 2012, Charoensin, 2014 and Zhu et al., 2019).

Most households in Malawi depend on vegetables and other plant foods for micronutrients and other vitamins. Consumption of traditional vegetables in Malawi depends on the indigenous knowledge and consumption varies from one region to another. Only few studies have been done on nutritional profiles of traditional vegetables from Malawi (Jinazali et al., 2017, Chatepa et al., 2020). Furthermore, not much has been explored on the bioactive phytochemicals and antioxidant activities of traditional vegetables. Data on nutritional profiles, phytochemicals and antioxidant activity can help to estimate the potential contribution of the vegetables to human nutrition and health. The present study was therefore aimed at evaluating the nutrient contents, phytochemical compounds and antioxidant activities of five major traditional vegetables from Malawi, namely Corchorus olitorius, Amaranth hybridus, Moringa oleifera, Bidens pilosa and Ipomea batatas leaves.

\section{Materials and Methods}

\subsection{Sample Collection}

Traditional leafy vegetables in this study were collected from the fields in Mpemba (located $15.8818^{\circ} \mathrm{S}, 34.9672^{\circ} \mathrm{E}$ ) and Chikwawa (located $16.1958^{\circ} \mathrm{S}, 34.7741^{\circ} \mathrm{E}$ ) in the Southern 
region of Malawi. Leafy samples of Ipomea batatas, Corchorus olitorius, Amaranth hybridus, Moringa oleifera and Bidens pilosa were randomly harvested from cultivated farms. After harvest, the fresh vegetables were transferred to a food chemistry laboratory at Malawi University of Science and Technology in sealed plastic containers to process.

\subsection{Sample Preparation}

All the vegetable samples were cleaned by washing on running tap water then by distilled water to remove debris and other foreign matters. About $1 \mathrm{~kg}$ of each of the washed vegetables was air dried in a shade to dryness. After drying, vegetable samples were stored in plastic containers before analysis. Samples were wrapped in aluminium foils before they were placed in the containers.

\subsection{Nutritional Analysis}

\subsubsection{Analysis of Vitamin C}

The contents of vitamin $\mathrm{C}$ in the vegetables were determined using High Performance Liquid Chromatography method according to Vikram, et al. (2005). Vitamin C standards were prepared to make a calibration curve by preparing $(0,20,40,60,80,100) \mu \mathrm{g} / \mathrm{mL}$ of ascorbic acid from stock solution. Analysis of the samples and the standards was done using Shimadzu UV-VIS detector. Absorbances were read at $266 \mathrm{~nm}$ to get peak areas.

\subsubsection{Analysis of Carotenoids and Beta-carotene}

Column chromatography and UV Spectrophotometer were used to analyse total carotenoids and beta-carotene contents of the leafy vegetables. Carotenoids were extracted using acetone and petroleum ether (Rodriguez-Amaya \& Kimura, 2004). UV-Vis spectrophotometer (Shimadzu, UV mini 1240 model, Tokyo, Japan) was used to read the absorbances of the extract solutions. The standards of beta-carotene were made by preparing $(0,2,4,6,8$, and 10) $\mu \mathrm{g} / \mathrm{mL}$ from stock solution and its absorbances were read together with the vegetable extract solutions at a wavelength of $440 \mathrm{~nm}$ to determine the actual concentrations. Total carotenoids content was measured at a wavelength of $450 \mathrm{~nm}$.

\subsubsection{Analysis of Crude Fats}

Soxhlet method was used to analyse the composition of crude fats from the dry vegetables according to AOAC as described by Khodabux et al. (2007). Percentage of crude fats was found by using the following formula:

$$
\text { Crude fat } \quad(\%) \quad(W 1-W 2) * 100 / S
$$

(1)

Where $W 1=$ weight of empty flask, $W 2=$ weight of flask and extracted fat, and $S=$ weight of sample.

\subsubsection{Analysis of Ash and Minerals}

Ash and minerals in the dry vegetable samples were extracted according to AOAC method 
followed by analysis of minerals as described by Gokoglu et al. (2004) . Ash percentages were found by weighing the samples before and after ashing using analytical balance and the differences were used to calculate the percentages of ash in the vegetables. Identification and quantification of minerals from the vegetables was done by the Atomic Absorption Spectrophotometer (AAS), Shimadzu Japan. To plot the calibration curves, minerals standards were prepared from stock solutions at varying increasing concentrations.

\subsection{Phytochemicals Analysis}

\subsubsection{Extraction of samples for Phytochemicals Analysis}

Extraction of samples for analysis of total phenolics, total flavonoids and antioxidants activity was performed according to the method described by Harborne (1998). A $2 \mathrm{~g}$ of each leaf sample was blended using $20 \mathrm{ml}$ of $95 \%$ ice cold methanol in a mortar. The leafy samples were thereafter vortexed and incubated at room temperature for 48hours in the dark. The extract was then passed through a cheese cloth to remove suspended materials and was then centrifuged at 13,000 rpm for 10 minutes. The supernatants were collected in test tubes after passing the extract through $0.45 \mu \mathrm{L}$ filters before analysis.

\subsubsection{Determination of Total Phenolic Compounds}

Folin Ciocalteu method was used to determine total phenolic compounds and standard Gallic acid was used for quantification (Ainsworth \& Gillespie, 2007). Different concentrations of the standard $(0,50,100,200,300,400$ and $500 \mathrm{mg} / \mathrm{L})$ were prepared using Gallic acid. To 1 $\mathrm{mL}$ of the standard and sample extract, $2 \mathrm{~mL}$ of $10 \%$ (v/v) Folin Ciocalteu reagent was added and vortexed and $4 \mathrm{~mL}$ of saturated $\mathrm{Na}_{2} \mathrm{CO}_{3}$ solution was also added. Absorbances of the samples were measured at $765 \mathrm{~nm}$ using UV-vis spectrophotometer after leaving the mixture at room temperature for 2 hours. A curve for the standard was plotted using absorbances of Gallic acid standard concentrations. The concentrations of total phenolic compounds in the samples were deduced from the standard curve and were expressed as Gallic acid equivalents (GAE) per $100 \mathrm{~g}$ of the sample (g GAE/100g DW).

\subsubsection{Determination of Total Flavonoids}

Aluminum chloride colorimetric method was used to determine the concentrations of total flavonoids in the leafy vegetables as described by Ebrahimzadeh et al. (2008). $1 \mathrm{~mL}$ of the methanolic leaf extract and $4 \mathrm{~mL}$ of distilled water were mixed in a $10 \mathrm{~mL}$ volumetric flask. $0.3 \mathrm{~mL}$ of $5 \%$ sodium nitrite solution was added to the mixture after 3 minutes followed by $0.3 \mathrm{~mL}$ of $10 \%$ aluminum chloride after another 3 minutes. $2 \mathrm{~mL}$ of $1 \mathrm{M}$ sodium hydroxide was added and the volume was made up to $10 \mathrm{~mL}$ with distilled water after 5 minutes. Absorbances were read at $415 \mathrm{~nm}$ using UV-Vis spectrophotometer (Shimadzu, UV mini 1240 model, Tokyo, Japan). Total flavonoids concentrations were calculated from the standard curve prepared using quercetin. The results were expressed as quercetin equivalents (QE) per $100 \mathrm{~g}$ of dry sample (g QE/100g DW).

\subsubsection{Determination of Tannins}

The concentrations of tannins from the vegetables were evaluated using Vanillin- $\mathrm{HCl}$ method 
according to Millet (2013). UV-Vis spectrophotometer (Shimadzu, UV mini 1240 model, Tokyo, Japan) was used to measure the absorbances of the vegetable extracts, standard solutions and the blank solution at the wavelength of 500nm after adding Vanillin-HCL reagent. Catechin was used as standard for quantification of tannins from the vegetables and tannins concentration was expressed as milligram of catechin equivalent (CE) per $100 \mathrm{~g}$ of dry sample (mg CE/100g).

\subsubsection{Determination of Antioxidant Activities}

The antioxidant activities of the vegetable samples were determined by using the free radical scavenging activity method adopted from Ebrahimzadeh et al. (2008). The radical scavenging activities of the methanolic leaf extracts against 2, 2-diphenyl-1-picryl hydrazyl (DPPH) radical were determined by UV-Vis spectrophotometer. Antioxidant standard (vitamin C) was prepared at the concentrations similar to that of the extracts. From each of the prepared concentrations of the extracts and vitamin $\mathrm{C}$ standards, $1 \mathrm{~mL}$ of the stock solution was transferred into each test tube. $3 \mathrm{~mL}$ of methanol was then added to each test tube followed by $0.5 \mathrm{~mL}$ of $1 \mathrm{mM}$ DPPH in methanol. A blank solution was prepared containing the same amount of methanol without extract but with $0.5 \mathrm{~mL}$ of $1 \mathrm{mM}$ DPPH. Absorbances were read at $517 \mathrm{~nm}$ using UV-Vis spectrophotometer. DPPH radical scavenging activity was calculated using the following formula:

$$
\mathrm{DPPH} \text { radical scavenging activity }(\%)=\{[\mathrm{Ab}-\mathrm{Aa}] \div \mathrm{Ab}\} * 100
$$

Where Aa is the absorption of extract solution (sample) and Ab is the absorption of blank.

\subsection{Analysis of Data}

STATA software (STATA 14.0, Texas, USA) was used for analysis of data. The data comparison among the vegetables was made by one way analysis of variance (ANOVA) using Bonferroni test. Statistical significance was set at $\mathrm{P}<0.05$. Samples were analysed in triplicates.

\section{Results and Discussion}

\subsection{Vitamins and Crude Fats Composition of the Traditional Vegetables}

Data for vitamin C (ascorbic acid), beta-carotene, total carotenoids and crude fats is in Table 1. Concentrations of vitamin $\mathrm{C}$ ranged from $7.93 \mathrm{mg} / 100 \mathrm{~g}$ to $35.81 \mathrm{mg} / 100 \mathrm{~g}$. Vitamin $\mathrm{C}$ concentrations in the vegetables from highest to lowest were in the order of sweet potato leaves > black jack > Moringa oleifera > jute mallow and Amaranth hybridus leaves respectively. Sweet potato leaves had the highest concentration of vitamin C. Vitamin C concentrations in Moringa oleifera and jute mallow leafy vegetables were statistically similar ( $\mathrm{P}>0.05)$. The concentration of vitamin C in Moringa oleifera from this study (21.23-30.69 $\mathrm{mg} / 100 \mathrm{~g}$ ) was in agreement with that of Moringa oleifera from three different countries as reported by Ecker (2003) with a range of $20-55 \mathrm{mg} / 100 \mathrm{~g}$. However, in this study Moringa oleifera had lower concentration of vitamin C than what was reported by Ademiluyi (2018) where $41.17 \mathrm{mg} / \mathrm{g}$ was reported in air-dried Moringa oleifera. The vitamin C content of jute 
mallow in this study $(22.85 \mathrm{mg} / 100 \mathrm{~g})$ was slightly lower compared to results reported by Oboh et al. (2009), with a concentration of $32.6 \mathrm{mg} / 100 \mathrm{~g}$. The differences could be due to different growing condition, sample preparation procedures and methods of analysis. Vitamin $\mathrm{C}$ has high antioxidant activity and plays a role of maintaining healthy skin (Rangani et al., 2018).

The range of beta-carotene in the vegetables was $(829.68-5,791.64) \mu \mathrm{g} / 100 \mathrm{~g}$ (Table 1). A 50g serving from these vegetables would provide $2.7-18.6 \%$ of recommended dietary allowances (RDAs) of vitamin A for lactating women aged 19 to 50 years (considering that 1 retinal activity equivalent $(1 \mathrm{RAE})=12 \mu \mathrm{g} \beta$-carotene) with reference to Food and Nutrition Board, Institute of Medicine, National Academics of 2005. Moringa oleifera had significantly $(\mathrm{P}<0.05)$ higher concentration of beta-carotene than the other vegetables in this study. Jute mallow, black jack, sweet potato leaves and Amaranth hybridus leaves had statistically similar ( $\mathrm{P}>0.05)$ concentrations of beta-carotene. Vitamin $\mathrm{C}$ and beta-carotene acts as antioxidants in the body and can help to reduce the risk of diseases such as diabetes mellitus and other cardiovascular diseases (Yang \& Keding, 2009).

Table 1. Means of Crude fat, Total Carotenoids, Betacarotene and Ascorbic acid

\begin{tabular}{|c|c|c|c|c|}
\hline Vegetable leaves & $\begin{array}{l}\% \text { Crude } \\
\text { fat }\end{array}$ & $\begin{array}{l}\text { Total Carotenoids } \\
(\mu \mathrm{g} / 100 \mathrm{~g} \mathrm{DW})\end{array}$ & $\begin{array}{l}\text { Betacarotene } \\
(\mu \mathrm{g} / 100 \mathrm{~g} \mathrm{DW})\end{array}$ & $\begin{array}{l}\text { Vitamin C } \\
(\mathrm{mg} / 100 \mathrm{~g} \\
\text { DW) }\end{array}$ \\
\hline Sweet potato & $1.91 \pm 0.06^{\mathrm{a}}$ & $3,165.32 \pm 542.46^{\mathrm{b}}$ & $1,055.11 \pm 180.95^{\mathrm{b}}$ & $35.81 \pm 1.18^{\mathrm{a}}$ \\
\hline Black jack & $2.18 \pm 0.45^{\mathrm{a}}$ & $3,726.62 \pm 468.11^{b}$ & $1,242.21 \pm 156.04^{b}$ & $28.78 \pm 2.65^{\mathrm{ab}}$ \\
\hline Moringa oleifera & $2.28 \pm 0.48^{\mathrm{a}}$ & $15,041.59 \pm 2,569.15^{\mathrm{a}}$ & $5,791.64 \pm 1671.43^{\mathrm{a}}$ & $25.48 \pm 4.71^{\mathrm{b}}$ \\
\hline Jute mallow & $1.32 \pm 0.62^{\mathrm{a}}$ & $6,459.86 \pm 142.54^{\mathrm{b}}$ & $2,153.29 \pm 47.51^{\mathrm{b}}$ & $22.85 \pm 0.82^{b}$ \\
\hline $\begin{array}{l}\text { Amaranth } \\
\text { Hybridus }\end{array}$ & $1.07 \pm 0.40^{\mathrm{a}}$ & $1,708.68 \pm 221.91^{\mathrm{b}}$ & $829.68 \pm 453.56^{b}$ & $7.93 \pm 0.90^{c}$ \\
\hline
\end{tabular}

Note: The values in the same column with the same superscripts are statistically similar at $\mathrm{P}<0.05$ by Bonferroni ANOVA test, and values are means $\pm \mathrm{SD}(\mathrm{n}=3)$; DW-dry weight.

\subsection{Minerals and Ash Composition of the Vegetables}

Table 2 presents ash and minerals (iron, zinc, copper and calcium) composition of the five traditional leafy vegetables. Ash composition of the vegetables ranged from $10.33 \%$ to $16.61 \%$. Amaranth hybridus had the highest percentage of ash. Iron concentration was in the range $(37.22-48.21) \mathrm{mg} / 100 \mathrm{~g}$ DW. A $50 \mathrm{~g}$ serving from these vegetables would provide $68.50-88.90 \%$ of recommended dietary allowances (RDAs) of iron for pregnant women aged 14 to 50 years. Sweet potato leaves had the highest concentration of iron. The iron 
concentration of Moringa oleifera in this study $(37.22 \pm 1.07 \mathrm{mg} / 100 \mathrm{~g})$ was statistically similar to that reported by Res et al. (2003), with iron content of $360.4 \mathrm{mg} / \mathrm{kg}$.

The range of zinc concentrations was (4.42-10.59) $\mathrm{mg} / 100 \mathrm{~g}$ DW. A $50 \mathrm{~g}$ serving from these vegetables would provide $20-48 \%$ of recommended dietary allowances (RDAs) of zinc for pregnant women aged 19-50 years. Moringa oleifera had the highest concentration of zinc and jute mallow had the least concentration. The amount of zinc in Moringa oleifera from this study $(10.59 \pm 2.32 \mathrm{mg} / 100 \mathrm{~g} \mathrm{DW})$ is higher than that reported by Res et al. (2003), where they found $24.8 \mathrm{mg} / \mathrm{kg}$ from dried Moringa leaf samples.

The concentrations of copper are as presented in Table 2. Its range was (1.29-3.90) $\mathrm{mg} / 100 \mathrm{~g}$ DW. Moringa oleifera had the least concentration of copper. Res et al. (2003) reported higher $(4.31 \mathrm{mg} / 100 \mathrm{~g})$ concentration of copper in Moringa oleifera dry leaves than what was found $(1.29 \pm 0.13 \mathrm{mg} / 100 \mathrm{~g})$ in this study. Copper plays a role in iron metabolism and is also involved in biological processes including having antioxidant function and immune function (Muriel et al., 2016). Calcium concentrations were in the range of (150.86-559.75 mg/100g DW. Moringa oleifera had the highest concentration of calcium as compared to the other vegetables in this study. Calcium plays a role of maintaining healthy bones and reduces risks of osteoporosis and osteomalacia.

Table 2. Mean ash (\%) and minerals (mg/ 100g DW) content in dry traditional vegetables

\begin{tabular}{|c|c|c|c|c|c|}
\hline $\begin{array}{l}\text { Vegetable } \\
\text { leaves }\end{array}$ & Ash (\%) & $\operatorname{Iron}(n=3)$ & $\operatorname{Zinc}(n=3)$ & $\operatorname{Copper}(n=3)$ & Calcium(n=3) \\
\hline Sweet potato & $11.62 \pm 0.15^{\mathrm{bc}}$ & $48.21 \pm 3.18^{\mathrm{a}}$ & $5.47 \pm 2.38^{\mathrm{b}}$ & $3.20 \pm 0.05^{\mathrm{b}}$ & $242.95 \pm 46.57^{b c}$ \\
\hline Black jack & $11.67 \pm 0.53^{b}$ & $40.43 \pm 3.61^{b}$ & $7.27 \pm 0.10^{\mathrm{ab}}$ & $3.90 \pm 0.15^{\mathrm{a}}$ & $150.86 \pm 26.10^{c}$ \\
\hline $\begin{array}{l}\text { Moringa } \\
\text { oleifera }\end{array}$ & $10.60 \pm 0.13^{b c}$ & $37.22 \pm 1.07^{\mathrm{b}}$ & $10.59 \pm 2.32^{\mathrm{a}}$ & $1.29 \pm 0.13^{\mathrm{d}}$ & $559.75 \pm 102.81^{\mathrm{a}}$ \\
\hline Jute mallow & $10.33 \pm 0.78^{c}$ & $37.30 \pm 2.68^{b}$ & $4.42 \pm 0.12^{\mathrm{b}}$ & $1.98 \pm 0.07^{\mathrm{c}}$ & $176.54 \pm 48.68^{c}$ \\
\hline $\begin{array}{l}\text { Amaranth } \\
\text { hybridus }\end{array}$ & $16.61 \pm 0.26^{\mathrm{a}}$ & $44.89 \pm 1.74^{\mathrm{ab}}$ & $5.70 \pm 0.20^{\mathrm{b}}$ & $1.55 \pm 0.04^{\mathrm{d}}$ & $396.10 \pm 29.46^{\mathrm{ab}}$ \\
\hline
\end{tabular}

Note: The values in the same column with the same superscripts are statistically similar at $\mathrm{P}<0.05$ by Bonferroni ANOVA test, and values are means $\pm \mathrm{SD}(\mathrm{n}=3)$. DW - dry weight.

\subsection{Phytochemical Constituents of the Vegetables}

The total phenolic content (TPC) in the vegetables was in the range of $0.98 \mathrm{~g} \mathrm{GAE} / 100 \mathrm{~g}$ to $3.89 \mathrm{~g} \mathrm{GAE} / 100 \mathrm{~g}$ DW in the vegetables (Figure 1). Concentration of TPC was highest in 


\section{Macrothink}

black jack leafy vegetables (3.85 g GAE/100g DW) while Amaranth hybridus leafy vegetables had the least concentration (0.98 g GAE/100g DW). Singh et al. (2017) reported TPC value of $7.2 \mathrm{~g} \mathrm{GAE} / 100 \mathrm{~g}$ in black jack leaves. This value was slightly higher than the TPC value found in black jack leaves from this study (3.85 g GAE/100g DW). The difference could be due to different growing conditions. The concentration of TPC in Amaranth hybridus from this study agrees with that reported by Chitindingu et al. (2006) where they found $1.127 \mathrm{mg}$ GAE/100mg DW. The slight differences could be due to different growing conditions such as soil and climate. Sweet potato leaves had $2.20 \mathrm{mg}$ GAE/100g DW of TPC. Similarly, Fu et al. (2016) found the TPC of sweet potato leaves in the range of 2.3-4.38 mg GAE/g from different aqueous extracts. Moringa oleifera and jute mallow leaves had statistically similar concentrations of TPC. The TPC from the extract of jute mallow in this study was higher $(3.0 \mathrm{~g} \mathrm{GAE} / 100 \mathrm{~g})$ than what was reported by Oboh et al. (2009). The TPC value of the extract of Moringa oleifera from this study $(3.10 \mathrm{~g} / 100 \mathrm{~g})$ was similar to that reported by Ecker (2003) in Moringa samples from three different countries (2.94-4.25 g GAE/100g). The mean TPC value of Moringa oleifera reported in this study is slightly lower than what was reported by Ademiluyi (2018) in air-dried samples (5.94 g GAE/100g) of Moringa oleifera. Amaranth hybridus had the least $(0.98 \mathrm{~g} \mathrm{GAE} / 100 \mathrm{~g})$ concentration of TPC compared to the other vegetables. The differences in concentration among these vegetables could be due to the nature of the vegetables leaves and the growing conditions.

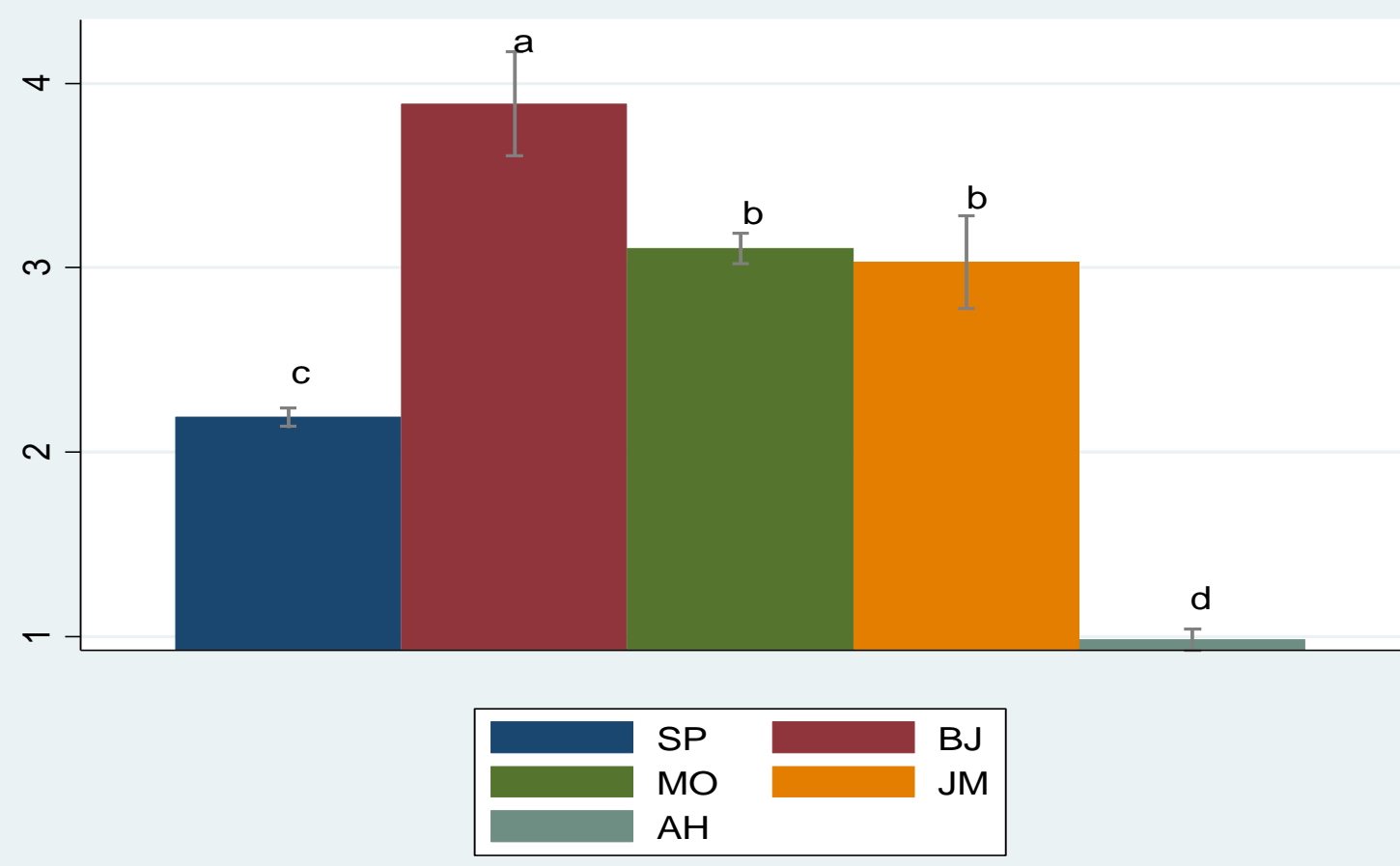

Figure 1. Total phenolics content (TPC) of the traditional leafy vegetables expressed as grams Gallic acid equivalent per 100g (g GAE/100g) on dry weight basis. JM- Jute mallow; BJBlack jack; SP-Sweet potato; AH- Amaranth hybridus and MO- Moringa oleifera. Bars with values with the same letters are statistically similar $(\mathrm{P}<0.05)$ using Bonferroni ANOVA test, and values are means $\pm \mathrm{SD}(\mathrm{n}=3)$ 


\section{Macrothink}

Figure 2 presents total flavonoids content (TFC) of the five traditional vegetables. Moringa oleifera and black jack leaves had the highest concentrations of TFC in comparison to the other vegetables, with Amaranth hybridus having the least $(0.90 \mathrm{~g} \mathrm{QE} / 100 \mathrm{~g})$ concentration. Flavonoid and phenolic compounds are responsible for the antioxidant activity in plants because they chelate metals, quench singlet oxygen and act as reducing agents (Deveci \& Çayan, 2019). Flavonoids are found in plants in large quantities compared to other polyphenolic compounds that are found in plants and are responsible for anti-inflammatory, anticancer and antioxidant activity (Rangani et al., 2018). Higher concentration of TFC (123.3 $\mu \mathrm{g} \mathrm{QE} / \mathrm{mg}$ ) was found in black jack leaves as reported by Singh et al. (2017) compared to the findings in this study ( $2.66 \mathrm{~g} \mathrm{QE} / 100 \mathrm{~g})$. The differences might be due to different growing conditions such as soil and climate. The aqueous extract of jute mallow from this study had higher TFC $(1.96 \mathrm{~g}$ QE/100g) than what was reported by Oboh et al., (2009) with TFC value of $227.8 \mathrm{mg}$ QE/100g. Furthermore, the TFC value of Moringa oleifera $(2.87 \mathrm{~g} \mathrm{QE} / 100 \mathrm{~g})$ in this study was slightly lower than that reported by Ademiluyi (2018) with TFC value of $5.83 \mathrm{~g} \mathrm{QE} / \mathrm{g}$ in air-dried Moringa samples.

The data for total carotenoids content (TCC) of the leafy vegetables is presented in Table 1. TCC concentrations were in the range of 1,708.08 - 1, 5041.59 $\mu \mathrm{g} / 100 \mathrm{~g}$ DW. Moringa oleifera had the highest concentration of TCC as compared to the other vegetables. TCC concentrations in Amaranth hybridus, jute mallow, black jack and sweet potato leaves were statistically similar $(\mathrm{P}<0.05)$. Although TCC concentrations were statistically similar in the four traditional vegetables, Amaranth hybridus had the least concentration.

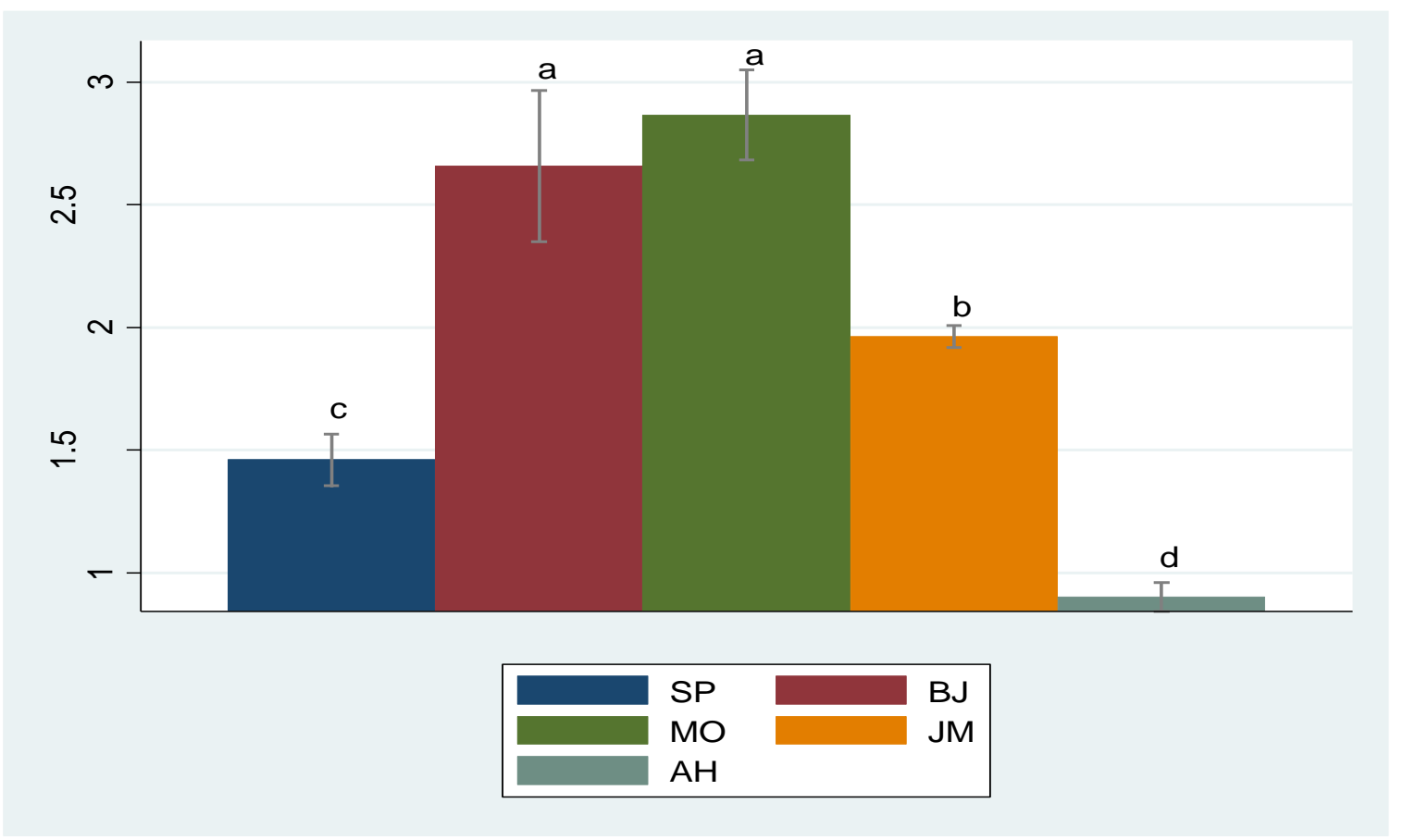

Figure 2. Total flavonoids content (TFC) of five traditional leafy vegetables expressed as grams quercetin equivalent per $100 \mathrm{~g}$ (g QE/100g) on dry weight basis. JM- Jute mallow; BJBlack jack; SP-Sweet potato; AH- Amaranth hybridus and MO- Moringa oleifera. Bars with values with the same letters are statistically similar $(\mathrm{P}<0.05)$ using Bonferroni ANOVA test, 
and values are means $\pm \mathrm{SD}(\mathrm{n}=3)$

Tannins concentrations are as indicated in Table 3. It ranged from $42.94 \mathrm{mg}$ CE/100g to 79.63 $\mathrm{mg}$ CE/100g DW. Moringa oleifera leaves had the highest concentration of tannins compared to other vegetables. However, the concentrations of tannins in Moringa oleifera, black jack and sweet potato leaves were statistically similar. Tannins concentration of Moringa oleifera was higher than that reported by Ademiluyi (2018) in samples of air dried and sun dried Moringa oleifera leaves. Jute mallow had the lowest concentration of tannins and it was statistically similar to Amaranth hybridus. Tannins are plant phenolic compounds with biological activities and also act as phytochemicals with antioxidant effects in the body.

Table 3. Mean concentrations of Tannins (mg CE/100g DW) in five traditional vegetables

\begin{tabular}{|c|c|}
\hline Vegetable leaves & Tannins \\
\hline Black jack & $77.16 \pm 23.27^{\mathrm{a}}$ \\
\hline Moringa oleifera & $79.63 \pm 20.15^{\mathrm{a}}$ \\
\hline Jute mallow & $42.94 \pm 17.48^{b}$ \\
\hline Sweet potato & $61.18 \pm 15.48^{a}$ \\
\hline Amaranth hybridus & $47.91 \pm 3.53^{\mathrm{b}}$ \\
\hline
\end{tabular}

Note: Tannins values with the same superscripts are statistically similar at $\mathrm{P}<0.05$ by Bonferroni ANOVA test, and values are means $\pm \mathrm{SD}, \mathrm{n}=3$; DW - dry weight; CE - Catechin equivalent.

\subsection{DPPH Radical Scavenging Activities}

DPPH radical scavenging activities (Figure 4) from the methanolic vegetable extracts varied from one vegetable to another. The half maximum inhibitory concentration ( $\left.\mathrm{IC}_{50}\right)$ of the vegetable extracts ranged from $12 \mu \mathrm{g} / \mathrm{mL}$ to $125 \mu \mathrm{g} / \mathrm{mL}$ in the different vegetables compared to the standard (Vitamin C) which had an $\mathrm{IC}_{50}$ value of $5 \mu \mathrm{g} / \mathrm{ml}$ as presented in Table 4. Black jack leaf extract had the highest DPPH radical scavenging activity with $\mathrm{IC}_{50}$ value of 12 $\mu \mathrm{g} / \mathrm{mL}$. However, Singh et al. (2017) reported $80.45 \mu \mathrm{g} / \mathrm{mL}$ as IC 50 of black jack leaf methanolic extracts. The $\mathrm{IC}_{50}$ values from extracts of jute mallow and Moringa oleifera were $16 \mu \mathrm{g} / \mathrm{mL}$ and $18 \mu \mathrm{g} / \mathrm{mL}$ respectively. Sweet potato leaves and Amaranth hybridus leaves had $22 \mu \mathrm{g} / \mathrm{mL}$ and $125 \mu \mathrm{g} / \mathrm{mL}$ respectively. The DPPH radical scavenging activity curves for the vegetable extracts and that of the standard (Vitamin C) are presented in Figure 4. The antioxidant activities might be attributed to vitamin C, TPC, TFC, Tannins and beta-carotene found in the vegetables as these compounds are known to have antioxidant effects and can scavenge free radicals. Concentrations of these compounds in the vegetables however, vary from one plant species to another as observed from the individual concentrations from the data presented (Figure 1, Figure 3, Table 1 and Table 3). IC 50 value of Amaranth hybridus $(125 \mu \mathrm{g} / \mathrm{mL})$ was much higher compared to the rest of the vegetables meaning that it had the lowest radical scavenging activity. Vitamin C content of Amaranth hybridus was the lowest in comparison to the other vegetable extracts. TPC and TFC values in Amaranth hybridus were 


\section{Macrothink

the lowest compared to the rest of the vegetable extracts. The Tannins contents of black jack, Moringa oleifera and sweet potato leaves were statistically similar. Current studies have shown increased investigations of antioxidant compounds in plants because natural food antioxidants are on demand (Deveci \& Çayan, 2019). In order to evaluate the ability of extracts to scavenge free radicals, DPPH radical scavenging assay is commonly used (Rjeibi, 2017). DPPH radical scavenging assay is widely used and it can determine the capability of an extract to scavenge free radicals; thus the lower the value of $\mathrm{IC}_{50}$, the higher the antioxidant potential (Rangani et al., 2018).

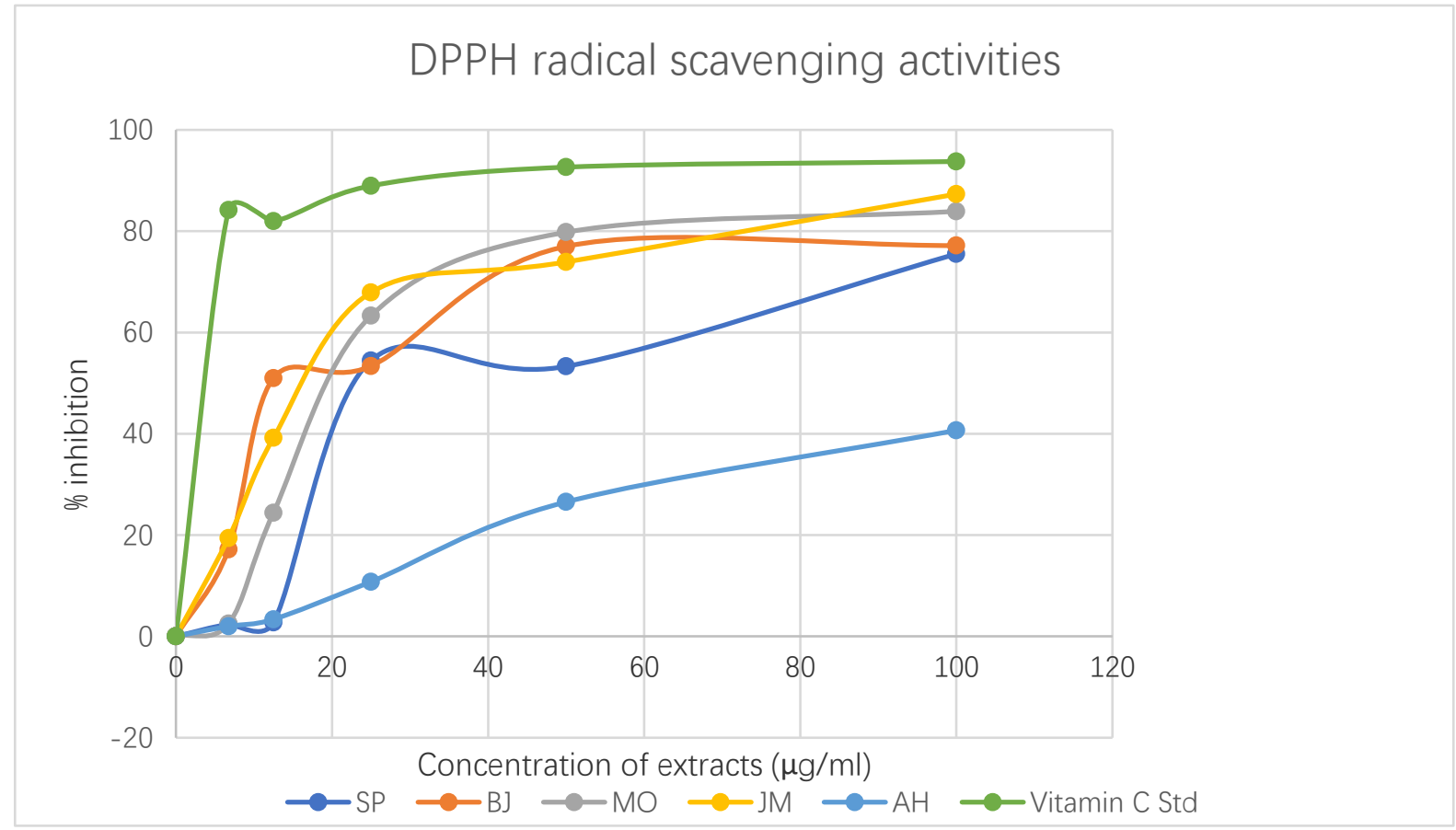

Figure 3. DPPH radical scavenging activities of five traditional leafy vegetables with different concentrations of leaf extracts. JM- Jute mallow; BJ- Black jack; SP-Sweet potato; AH- Amaranth hybridus and MO- Moringa oleifera and vitamin C Std-Vitamin C standard. 
Table 4. 50\% Inhibitory Concentration $\left(\mathrm{IC}_{50}\right)$ for the DPPH free radical scavenging activities of the vegetables

\begin{tabular}{|c|c|}
\hline Vegetable leaves & $\mathrm{IC}_{50}(\boldsymbol{\mu g} / \mathrm{ml})$ \\
\hline Vitamin C standard & 5.0 \\
\hline Sweet potato & 22.5 \\
\hline Black jack & 12.5 \\
\hline Moringa oleifera & 18.0 \\
\hline Jute mallow & 16.0 \\
\hline Amaranth hybridus & 122.5 \\
\hline
\end{tabular}

Note: Vegetables with low IC 50 values have high antioxidants activities

\section{Conclusion}

The findings from the present study show that the nutritional contents and phytochemicals constituents of traditional vegetables vary from one plant species to another. Moringa oleifera had the highest concentrations of beta-carotene, zinc, calcium, tannins, flavonoids and crude fats. Black jack leafy vegetables had the highest concentrations of total phenolic compounds with significant amount of total flavonoids. Vitamin $\mathrm{C}$ and iron contents were found to be highest in sweet potato leaves. DPPH radical scavenging activitity of the vegetables were in the order of black jack > jute mallow > Moringa oleifera $>$ sweet potato > Amaranth hybridus. The $\mathrm{IC}_{50}$ values of these vegetables tally with the DPPH radical scavenging activity of the vegetables. DPPH radical scavenging activities are attributed to the plant phytochemicals and antioxidant vitamins. The attributes include total phenolic compounds, total flavonoids, tannins, vitamin $\mathrm{C}$ and beta-carotene. The concentrations of these compounds in the vegetables vary from one vegetable species to another. Lower IC 50 values indicate higher radical scavenging activity hence better antioxidant potential. The results suggests that the traditional vegetables under this study can contribute to improved human nutrition and have potential to inhibit free radicals that contribute to degenerative diseases and diseases related to oxidative stress such as cancer and diabetes mellitus.

\section{References}

Ademiluyi, A. O. (2018). Drying alters the phenolic constituents, antioxidant properties, amylase, and $\alpha$ - glucosidase inhibitory properties of Moringa ( Moringa oleifera ) leaf, (July), 21232133. https://doi.org/10.1002/fsn3.770

Ainsworth, E. A., \& Gillespie, K. M. (2007). Estimation of total phenolic content and other oxidation substrates in plant tissues using Folin-Ciocalteu reagent. Nature Protocols, 2(4), 875-877. https://doi.org/10.1038/nprot.2007.102

Ayasan, T. (2015). Türk Tarım - Gıda Bilim ve Teknoloji Dergisi Moringa ( Moringa Oleifera )' nin Kanatl ve Ruminant Hayvan, 3(6), 425-429. https://doi.org/10.24925/turjaf.v3i6.425-429.327 
Charoensin, S. (2014). Antioxidant and anticancer activities of Moringa oleifera leaves, 8(7), 318-325. https://doi.org/10.5897/JMPR2013.5353

Chatepa, L., Resources, N., Masamba, K. G., \& Resources, N. (2020). Proximate and phytochemical composition of selected indigenous leafy vegetables consumed in Malawi, (October). https://doi.org/10.5897/AJFS2020.1979

Chitindingu, K., Ndhlala, A.R., Chapano, C., Benhura, M.A., \& Muchuweti, M . (2006). Phenolic compound content, profiles and antioxidant activities of Amaranth hybridus (Pigweed), Brachiaria brizantha (Upright brachiaria) and Panicum maximum (Guinea grass). Journal of Food Biochemistry, 31(2007), 206-216. https://doi.org/10.1111/j.1745-4514.2007.00108.x

Deveci, E., \& Çayan, G. T. (2019). Phytochemical contents , antioxidant effects , and inhibitory activities of key enzymes associated with Alzheimer â $€^{\mathrm{TM}} \mathrm{s}$ disease, ulcer, and skin disorders of Sideritis albiflora and Sideritis leptoclada, (September), 1-11. https://doi.org/10.1111/jfbc. 13078

Ebrahimzadeh, M. A., Pourmorad, F., \& Bekhradnia, A. R. (2008). Iron chelating activity , phenol and flavonoid content of some medicinal plants from Iran, 7(18), 3188-3192. https://doi.org/10.5897/AJB08.476

Ecker, K. L. B. (2003). Antioxidant Properties of Various Solvent Extracts of Total Phenolic Constituents from Three Different Agroclimatic Origins of Drumstick Tree ( Moringa oleifera Lam .) Leaves AND, 2144-2155. https://doi.org/10.1021/jf020444+

Etcheverry, P., Grusak, M. A., \& Fleige, L. E. (2012). Application of in vitro bioaccessibility and bioavailability methods for calcium, carotenoids, folate, iron , magnesium , polyphenols, zinc, and vitamins B $6, \mathrm{~B} 12, \mathrm{D}$, and E, 3(August), 1-22. https://doi.org/10.3389/fphys.2012.00317

Fu, Z., Tu, Z., Zhang, L., Wang, H., Wen, Q., \& Huang, T. (2016). Author' s Accepted Manuscript solvents of various polarities Antioxidant activities and polyphenols of sweet potato ( Ipomoea batatas L .) leaves extracted with solvents of various polarities. https://doi.org/10.1016/j.fbio.2016.04.004

Gokoglu, N., Yerlikaya, P., \& Cengiz, E. (2004). Effects of cooking methods on the proximate composition and mineral contents of rainbow trout ( Oncorhynchus mykiss ), 84, 19-22. https://doi.org/10.1016/S0308-8146(03)00161-4

Gunathilake, K. D. P. P., \& Ranaweera, K. K. D. S. (2018). Effect of Different Cooking Methods on Polyphenols , Carotenoids and Antioxidant Activities of Selected Edible Leaves, 1-12. https://doi.org/10.3390/antiox 7090117

Harborne, J. B. (1998). Phytochemical Methods; A Guide to Modern Techniques of Plant Analysis. Journal of Chemical Information and Modeling (Vol. 3). https://doi.org/10.1017/CBO9781107415324.004

Jinazali, H., Mtimuni, B., \& Chilembwe, E. (2017). Nutrient composition of cat's whiskers 
( Cleome gynandra L .) from different agro ecological zones in Malawi, 11(January), 24-29. https://doi.org/10.5897/AJFS2016.1478

Khodabux, K., Sophia, M., Omelette, S. L., Jhaumeer-laulloo, S., Ramasami, P., \& Rondeau, P. (2007). Food Chemistry Chemical and near-infrared determination of moisture , fat and protein in tuna fishes, 102, 669-675. https://doi.org/10.1016/j.foodchem.2006.05.057

Maria, C., Lorena, G., Ros, G., \& Nieto, G. (2019). Evaluation of nutritional profile and total antioxidant capacity of the Mediterranean diet of southern Spain, (May), 3853-3862. https://doi.org/10.1002/fsn3.1211

Mathew, B. B., Jatawa, S. K., \& Tiwari, A. (2012). Phytochemical analysis of Citrus limonum pulp and peel. International Journal of Pharmacy and Pharmaceutical Sciences, 4(2), 369-371.

Millet, P. (2013). Effects of Malting and Fermentation on Anti-Nutrient Reduction and Protein Digestibility of Red Sorghum, White Sorghum, 2(1), 41-49. https://doi.org/10.5539/jfr.v2n1p41

Muriel, A., Sabine, B., Marion, H., \& Esther, O. (2016). Dietary Copper and human health : current evidence and unresolved issues. https://doi.org/10.1016/j.jtemb.2016.02.006

Oboh, G., Raddatz, H., \& Henle, T. (2009). Characterization of the antioxidant properties of hydrophilic and lipophilic extracts of Jute (Corchorus olitorius) leaf, 7486. https://doi.org/10.1080/09637480902824131

Rangani, J., Kumari, A., Patel, M., Brahmbhatt, H., \& Parida, A. K. (2018). Phytochemical profiling, polyphenol composition, and antioxidant activity of the leaf extract from the medicinal halophyte Thespesia populnea reveal a potential source of bioactive compounds and nutraceuticals, (August), 1-16. https://doi.org/10.1111/jfbc.12731

Res, I. J. A., Lam, O., Stick, D., \& In, T. (2003). Manuscript Info Abstract Introduction: -ISSN: 2320-5407 Materials and Methods: - Results and Discussion, 5(8), 2101-2106. https://doi.org/10.21474/IJAR01/5277

Rjeibi, I. (2017). Characterization of Amaranthus spinosus collected from different regions : Phytochemical and biological properties, (January). https://doi.org/10.1111/jfbc.12397

Rodriguez-Amaya, D., \& Kimura, M. (2004). HarvestPlus Handbook for Carotenoid Analysis. HarvestPlus Technical Monographs, 59.

Singh, G., Passsari, A. K., Singh, P., Leo, V. V., Subbarayan, S., Kumar, B., ... Kumar, N. S. (2017). Pharmacological potential of Bidens pilosa L . and determination of bioactive compounds using UHPLC-QqQ LIT -MS / MS and GC / MS, 1-16. https://doi.org/10.1186/s12906-017-2000-0

Uusiku, N. P., Oelofse, A., Duodu, K. G., Bester, M. J., \& Faber, M. (2010). Nutritional value of leafy vegetables of sub-Saharan Africa and their potential contribution to human health: A review. Journal of Food Composition and Analysis, 23(6), 499-509. 
https://doi.org/https://doi.org/10.1016/j.jfca.2010.05.002

Vikram, V. B., Ramesh, M. N., \& Prapulla, S. G. (2005). Thermal degradation kinetics of nutrients in orange juice heated by electromagnetic and conventional methods. Journal of Food Engineering, $69(1)$ $31-40$. https://doi.org/https://doi.org/10.1016/j.jfoodeng.2004.07.013

Yang, R. Y., \& Keding, G. B. (2009). Nutritional contributions of important African indigenous vegetables. African Indigenous Vegetables in Urban Agriculture. https://doi.org/10.4324/9781849770019

Zhu, K., Huang, G., Xie, J., Zhou, X., Mu, J., \& Zhao, X. (2019). Preventive effect of flavonoids from Wushan Shencha ( Malus doumeri leaves ) on $\mathrm{CCl} 4$ - induced liver injury, (June), 3808-3818. https://doi.org/10.1002/fsn3.1243

\section{Copyright Disclaimer}

Copyright for this article is retained by the author(s), with first publication rights granted to the journal.

This is an open-access article distributed under the terms and conditions of the Creative Commons Attribution license (http://creativecommons.org/licenses/by/4.0/). 